\title{
ETHICS MANAGEMENT AT THE EUROPEAN COMMISSION
}

\author{
Daniela Viviane Abratzky ${ }^{1}$
}

DOI: https://doi.org/10.31410/ERAZ.2019.79

\begin{abstract}
This article reports on ethic management at the European Commission services and analyses its implementation measures. The European Commission is one of the most powerful international executives in the world and it is a very particular bureaucracy employing approximately 33.000 officials from twenty-eight Member States. The European Commission fulfils a very complex mandate by implementing EU policies and the budget as well as enforcing EU legislation. This challenging task is carried out in a unique structure, which combines professional bureaucratic processes with cultural richness. As of the year 2000 - driven by external pressure - European Commission enhanced its Ethic and Compliance policy by issuing guidelines and implementation measures at its headquarters; subsequently these efforts were also transported to the agencies, most of them being established in the Member States.
\end{abstract}

The article will analyse recognized Ethics management tools applied at the European Commission services with a special view to the efficiency of the role of an Ethics officer.

The article provides a concise overview on how Ethics policy is implemented in a highly complex and international structure. The reader will learn about organisational aspects of the European Commission and applied management techniques in terms of Ethical reforms.

The method is a sound literature research combined with a practical analysis of the current state of Ethics management in European bodies.

Keywords: Ethics program; European Commission; Ethics officer; Intercultural challenges.

\section{INTRODUCTION}

$\mathrm{T}$ he European Commission is a very particular bureaucracy employing approximately 33.000 staff (permanent and temporary contracts) from twenty-eight Member States. The European Commission fulfils a very complex mandate by implementing EU policies and the budget as well as enforcing EU legislation. This challenging task is carried out in an exclusive structure, which combines professional bureaucratic processes with cultural richness.

The view from the Commission (its official line) is that the EU civil service is unique in the world of international organisations. Cosmopolitan, multinational and multilingual, it has succeeded in creating a hybrid culture without parallel in the history of public administration: an organisational culture that harmoniously blends together the different administrative traditions of its member states to form a 'European' model of civil service with its own distinctive identity and ethos. A 'cultural melting pot' that supposedly combines all that is best from the different national civil services, the Commission is also portrayed as small, dynamic and efficient: a 'lean machine' in the words of its former Secretary General (Shore 2001). 
As of the year 2000 - driven by external pressure - European Commission enhanced its Ethic and Compliance policy by issuing guidelines and implementation measures at its headquarters; subsequently these efforts were also transported to the agencies, most of them being established in the Member States working merely with staff under temporary assignments.

\section{ETHICAL REFORMS AT THE EUROPEAN COMMISSION - BACKGROUND, DEVELOPMENT}

Following publication of a report on March 151999 of the Committee of Independent Experts (CIE), (MacMullen 1999)"plainCitation":"(MacMullen 1999 investigating allegations of "Fraud, Mismanagement and Nepotism in the European Commission" the entire College of Commissioners resigned, plunging the Commission into the most serious political crisis in its 42-year history (Shore 2001). The commission official David Spence, considered in 1994 the system of personal networks that important that they constitute a 'parallel system of administration' with its own rules, codes and career paths. The characteristics of this 'informal system' include:

- highly politicised senior management with close links to parties in power;

- an institutionalised system of national quotas (with particular posts being reserved for particular nationalities);

- a powerful Cabinet system, whose members act as bastions of national self-interest, and who constantly interfere in staffing matters (Ross, Jenson 1995);

- a host of informal methods used to circumvent the formal procedures, including the parachuting of political appointees into senior administrative positions (Ross, Jenson 1995).

Based on these findings the European Commission took action and developed a complex system of ethical measures laid down in policy papers and implementing rules in a first step at the EU headquarters in Brussels.

Gradually the European Commission took interventions which, over time, have engendered a rather comprehensive ethics infrastructure. The fall of the Santer Commission being one of the most damaging public scandal the Commission has ever known a White Paper on Reforming the Commission had been published (Union 2000, p. 200). At the beginning of this document the key principles of "good governance" are laid down. They are defined as "independence, responsibility, accountability, efficiency and transparency". These terms build the main principles for the ethics policy at commission services being put in practice in the following years in the eras of Neil Kinnock (1999 - 2004) and Siim Kallas (2004 - 2009) (Nastase 2016).

In March 2013 the Vice-President of the European Commission, Maroš Šefčovič is meeting with the Commission's internal ethics correspondents and the Ombudsman. In a speech he concludes: "In the European Union citizens have high expectations of their public administration at international level (Šefčovič 2013). European public servants are expected to serve the public interest with impartiality, loyalty and integrity. Following these core values Commission services established written codes that define standards for ethical behaviour" and he continues that citizens expect EU public servants to serve the public interest with impartiality, loyalty and integrity and to do so in all aspects of their daily work. Professional behaviour of EU civil servants is essential to build trust and the objective of the EU is to gain and to maintain credibility by guaranteeing that staff in Commission services carry out their duty in an impartial and accountable manner. 


\section{PUBLIC ETHICS AT THE EUROPEAN COMMISSION - STATE OF PLAY}

The Human Resource units in European institutions introduced various measures in order to implement the Ethics \& Integrity policy. They became an important part of the Human Resource Management. EU policy is built on trust and the European Commission undertook many efforts since 2013 to implement useful tools for an efficient Ethics Management deriving from the private economy. Still there is room for development especially with a view to the vast number of temporary assignments, mostly working at the European agencies.

The EU Agencies are performing tasks across a wide range of policy areas, with significant resources devoted to them. To date, there are more than 46 structures (32 decentralised Agencies, 7 Joint Undertakings and 6 Executive Agencies). In total, they employ more than 8,000 members of staff, mainly under temporary contracts (European Union 2019).

By now in most institutions the Human Resource units organise ethics trainings for all staff and it became common practice to introduce mandatory training also to newcomers. At the management level a stricter model is applied: managers recruited from outside the Commission are expected to sign a statement that they are aware of their ethical obligations (Nastase 2016).

Whereas the central European Commission services mostly work with civil servants, the agencies - most of them are established in the member states - contract a high percentage of staff on temporary assignments. An EU agency has its own legal personality. EU agencies were created in order to accomplish specific tasks for example in the field of scientific or technical know-how, or to bring together different interest groups facilitating a dialogue at European and international level. Also, the European Agencies provide trainings to its staff however the role of an Ethics officer or an Ethic correspondent is not established in a homogenic way.

\section{ETHICS PROGRAM; ETHICS MANAGEMENT, ETHICS OFFICER}

Following a study of Kaptein (2015)not only whether to adopt an ethics program, but also which components to adopt when. This study shows that unethical behavior occurs less frequently in organizations that have an ethics program than in organizations that do not have an ethics program. Nine components of ethics programs were identified and examined. The results show that there is a direct relationship between the number of components adopted and the frequency of observed unethical behavior. No relationship was found between pre-employment screening and unethical behavior, while the strongest relationship was discerned between accountability policies and unethical behavior. The study further reveals that the best sequence for adopting components of an ethics program is (1 unethical behaviour occurs less frequently in organizations that have an ethics program than in organizations that do not have an ethics program. The study examined nine components of ethics programs and the results show that there is a direct relationship between the number of components adopted and the frequency of observed unethical behaviour. The study reveals that the best sequence for adopting components of an ethics program is (1) a code of ethics, (2) ethics training and communication, (3) accountability policies, (4) monitoring and auditing, and (5) investigation and correction policies - all of which are directly related to less unethical behaviour - followed by (6) an ethics office ( $r$ ), (7) ethics report line, and (8) incentive policies of which are indirectly related to less unethical behaviour. 
These components are partially established in the Directorates General, for instance DG COMP (Directorate General for Competition) provides a well-structured internal website tackling some of the topics recommended by the literature.

One of these components is the role of the Ethics officer, in the Commission introduced as Ethics correspondents. The central Human Resource General Directorate in Brussels (DG HR) has developed a special website and a role of Ethics correspondents has been established in 2013 (Šefčovič). There are tools in place for monitoring ethical questions and factual issues such as a possible critical involvement of family members.

In the literature (mostly referring to the private sector) Chief Ethics and Compliance Officers ECOs) are high-level individuals who are primarily responsible for creating and maintaining organizational environments that aim to produce ethical and law - abiding employees and leaders. They do so by developing and distributing codes of conduct, designing and delivering training programs, developing and managing reporting lines and investigation systems, contributing to the design of performance management systems, and working to create ethical cultures and climate (Treviño, den Nieuwenboer, Kreiner, Bishop 2014).

In its guidelines the Commission recommends to its staff in case of questions or problems in the domain of ethics (Codes of conduct 2019). First of all, contact the local ethics correspondent. Each DG has appointed these staff experts to serve as the focal and first contact point for all ethics related issues, both for the services and their staff. When dealing with queries from staff the ethics correspondents act in confidence".

DG COMP integrated the role of their Ethics and Compliance Officer (ECO) in a special team called Resources, Ethics and Security being in charge of developing and implementing a thorough and efficient policy on ethics and security. The ECO monitors the consistent implementation of ethical rules and should be contacted for all practical questions regarding individual cases like external activities or conflicts of interest.

At the central level, unit DG HR - Ethics, Rights and Obligations is responsible for the general policy on ethics for staff members and serves as a reference point for the ethics correspondents.

For any questions regarding Commissioners and the overall broader coordination in respect of Public Service deontology, Public Service Ethics is the contact point.

When it comes to disciplinary questions the Commission asks the staff to direct these issues to IDOC and OLAF are the responsible services. (Investigation and Disciplinary Office and The European Anti-Fraud Office)

\section{STANDARDS AT EUROPEAN COMMISSION SERVICES WITH REGARD TO ETHICS \& INTEGRITY}

Ethical rules for European civil servants as well as for the vast number of employees on temporary basis are defined as practical rules and guidelines - a so-called Code of Conduct on Ethics \& Integrity for each institution of the European Commission services and the agencies (Ethics and the European Commission, 2013) 
Following (Kaptein 2015)not only whether to adopt an ethics program, but also which components to adopt when. This study shows that unethical behavior occurs less frequently in organizations that have an ethics program than in organizations that do not have an ethics program. Nine components of ethics programs were identified and examined. The results show that there is a direct relationship between the number of components adopted and the frequency of observed unethical behavior. No relationship was found between pre-employment screening and unethical behavior, while the strongest relationship was discerned between accountability policies and unethical behavior. The study further reveals that the best sequence for adopting components of an ethics program is ( 1 a code of ethics can be defined as "a distinct and formal document containing a set of prescriptions developed by and for a company to guide present and future behaviour on multiple issues of at least its managers and employees toward one another, the company, external stakeholder and/or society in general".

The Staff Regulations (and the CEOS - Conditions of Employment of Other Servants of the European Union) lay down the basic principles governing relations between the EU institutions and their staff (Regulation (EU, Euratom) No 1023/2013 of the European Parliament and of the Council of 22 October 2013 amending the Staff Regulations of Officials of the European Union and the Conditions of Employment of Other Servants of the European Union 2013). Of particular importance with regard to staff ethics and conduct is Title II of the Staff Regulations (see Annex 1 for full text), which deals with rights and obligations of officials and to which reference is frequently made in this Guide. The Staff Regulations are complemented by decisions and guidance in specific domains, as well as by the Financial Regulation.

\section{ETHICAL PRINCIPLES OF THE EUROPEAN COMMISSION}

Only by aspiring to the highest standards of integrity can you ensure the Commission's credibility. In fact, ethics is integrity in action. When we have integrity, we act ethically, which means adhering consistently to ethical standards and making sound decisions based on these standards. For the Commission to fulfil its mission of serving the common good and the public interest, your conduct and decision-making has to be irreproachable and guided by the following principles:

- Independence,

- Impartiality,

- Objectivity,

- Loyalty.

\section{CONCLUSION}

After a period of scandals and irregularities in the $90^{\text {th }}$ the European Commission reacted by implementing an Ethics and Compliancy policy. It is to be noted that this process has been driven by external pressure. This circumstance following the literature requires well defined and measurable rules are written down in a code of conduct. Such a code of conduct clearly states what employees should do to act in a responsible way. It also makes clear what external parties can expect from the company. In order to guarantee these expectations, compliance to the organisational rules needs to be enforced. Measurement and assessment systems in an organisation constitute a control system to ensure compliancy (Nijhof, Fisscher, Looise 2000).

A Code of Conduct is to date well established in all European Commission institutions, there are trainings in place as implementation tool and Ethics correspondents can be found mostly in 
the DGs. With the role of Ethics correspondents, the Commission decided to adopt an important component of Ethics management. Regarding disciplinary measures or cases of fraud the Commission asks its staff to direct these issues to the Fraud office or the Ombudsman. This can be seen as critical that for different questions or problems different teams have to be contacted.

As regards the other components for an effective ethics policy recommended by the literature it needs to be further analysed if the approach of the Commission is harmonized in its DGs and other institutions. A synergetic implementation of these components could show more effectiveness of an ethics program.

Remišová, Lašáková, Kirchmayer conclude that the number of elements as well as their combination may vary from organization to organization. The selection of specific Ethics Program components depends on the specific needs of the organization and on the economic, cultural, social, or political circumstances in which a particular organization is located (Remišová, Lašáková, Kirchmayer 2018). All those factors have high impact on the European Commission especially the cultural and social circumstances since the European Commission is a massive structure which can be compared with a conglomerate of many ministries in an intercultural environment. Given the fact that employees come from 28 member states implementing a harmonized Code of Conduct is a very challenging task. The role of the ECO can be considered as one of the most important components of the EU ethics policy, however further assessment would be required in order to see how and if different cultural perceptions are and should be addressed.

\section{REFERENCES}

[1] Codes of conduct, 2019. European Commission - European Commission [online]. [Accessed 19 June 2019]. Available from: https://ec.europa.eu/info/about-european-commission/service-standards-and-principles/codes-conduct_en

[2] DEBIHF, [no date]. European Union and the Politics of Culture. [online]. [Accessed 2 June 2019]. Available from: https://www.brugesgroup.com/media-centre/papers/8-papers/900-european-union-and-the-politics-of-culture

[3] EDWARDS, G. and SPENCE, D., 1994. The European Commission [online]. Longman Group. Longman Current Affairs. ISBN 978-0-582-21019-6. Available from: https://books. google.sk/books?id=QsaIAAAAMAAJ

[4] European Commission - PRESS RELEASES - Press release - SPEECH: Ethics and the European Commission, [no date]. [online]. [Accessed 17 February 2019]. Available from: http://europa.eu/rapid/press-release_SPEECH-13-201_en.htm

[5] EUROPEAN UNION, 2016. Agencies and other EU bodies. European Union [online]. 5 July 2016. [Accessed 17 February 2019]. Available from: https:/europa.eu/european-union/about-eu/agencies_en

[6] KAPTEIN, Muel, 2015. The Effectiveness of Ethics Programs: The Role of Scope, Composition, and Sequence. Journal of Business Ethics. December 2015. Vol. 132, no. 2, p. 415-431.DOI 10.1007/s10551-014-2296-3.

[7] MACMULLEN, Andrew, 1999. Fraud, mismanagement and nepotism: The Committee of Independent Experts and the fall of the European Commission 1999. Crime, Law and Social Change. 1 May 1999. Vol. 31, no. 3, p. 193-208. DOI 10.1023/A:1008382323009.

[8] NASTASE, Andreea, 2016. Public Ethics at the European Commission: Politics, Reform and Individual Views. ISBN 978-1-138-20378-5. 
[9] NIJHOF, André, FISSCHER, Olaf and LOOISE, Jan Kees, 2000. Coercion, Guidance and Mercifulness: The Different Influences of Ethics Programs on Decision-Making. Journal of Business Ethics. 1 September 2000. Vol. 27, no. 1, p. 33-42. DOI 10.1023/A:1006413308607.

[10] Regulation (EU, Euratom) No 1023/2013 of the European Parliament and of the Council of 22 October 2013 amending the Staff Regulations of Officials of the European Union and the Conditions of Employment of Other Servants of the European Union, 2013. [online]. 32013R1023. [Accessed 19 June 2019]. Available from: http://data.europa.eu/eli/ reg/2013/1023/oj/eng

[11] REMIŠOVÁ, Anna, LAŠÁKOVÁ, Anna and KIRCHMAYER, Zuzana, 2018. Influence of Formal Ethics Program Components on Managerial Ethical Behavior. Journal of Business Ethics [online]. 1 March 2018. [Accessed 17 February 2019]. DOI 10.1007/s10551-0183832-3. Available from: https://doi.org/10.1007/s10551-018-3832-3

[12] ROSS, George and JENSON, Jane, 1995. Reconsidering Jacques Delors' leadership of the European Union. Journal of European Integration. 1995. Vol. 39, no. 2, p. 113-127. DOI 1 0.1080/07036337.2016.1277718.

[13] ŠEFČOVIČ, Maroš, 2013. European Commission - PRESS RELEASES - Press release SPEECH: Ethics and the European Commission. [online]. March 2013. [Accessed 17 February 2019]. Available from: http://europa.eu/rapid/press-release_SPEECH-13-201_en.htm

[14] SHORE, 2001. European Union and the Politics of Culture. [online]. March 2001. [Accessed 2 June 2019]. Available from: https://www.brugesgroup.com/media-centre/papers/8-papers/900-european-union-and-the-politics-of-culture

[15] TREVIÑO, Linda Klebe, DEN NIEUWENBOER, Niki A., KREINER, Glen E. and BISHOP, Derron G., 2014. Legitimating the legitimate: A grounded theory study of legitimacy work among Ethics and Compliance Officers. Behavioral Ethics. 1 March 2014. Vol. 123, no. 2, p. 186-205. DOI 10.1016/j.obhdp.2013.10.009.

[16] UNION, Publications Office of the European, 2000. CELEX1, Reforming the Commission - A White Paper - Part I, /* COM/2000/0200 final */. [online]. 1 March 2000. [Accessed 2 June 2019]. Available from: https://publications.europa.eu/en/publication-detail/-/ publication/1b8f0479-f395-43bd-8e29-be98955bd8a2/language-en 